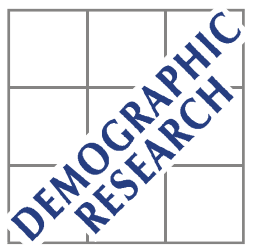

Demographic Research a free, expedited, online journal of peer-reviewed research and commentary in the population sciences published by the Max Planck Institute for Demographic Research Konrad-Zuse Str. 1, D-18057 Rostock · GERMANY www.demographic-research.org

DEMOGRAPHIC RESEARCH

VOLUME 25, ARTICLE 14, PAGES 465-490

PUBLISHED 16 AUGUST 2011

http://www.demographic-research.org/Volumes/Vol25/14/

DOI: 10.4054/DemRes.2011.25.14

Research Article

Household composition across the new

Europe: Where do the new

Member States fit in?

\title{
Maria Iacovou
}

\section{Alexandra J. Skew}

(C) 2011 Maria Iacovou \& Alexandra J. Skew.

This open-access work is published under the terms of the Creative Commons Attribution NonCommercial License 2.0 Germany, which permits use, reproduction \& distribution in any medium for non-commercial purposes, provided the original author(s) and source are given credit.

See http:// creativecommons.org/licenses/by-nc/2.0/de/ 


\section{Table of Contents}

1 Introduction 466

2 Data and methodology 468

2.1 Data 468

2.2 Relationships between household members 469

$\begin{array}{lll}2.3 & \text { Methodology } & 469\end{array}$

$3 \quad$ Household composition $\quad 470$

3.1 Living alone 474

3.2 The extended family 476

$4 \quad$ Children $\quad 478$

$5 \quad$ Older people 481

6 Conclusions $\quad 483$

$7 \quad$ Acknowledgements $\quad 484$

$\begin{array}{ll}\text { References } & 485\end{array}$

$\begin{array}{ll}\text { Appendix } & 489\end{array}$ 


\title{
Household composition across the new Europe: Where do the new Member States fit in?
}

\author{
Maria Iacovou ${ }^{1}$ \\ Alexandra J. Skew ${ }^{2}$
}

\begin{abstract}
In this paper we present indicators of household structure for 26 of the 27 countries of the post-enlargement European Union. As well as broad indicators of household type, we present statistics on single-person and extended-family households, and on the households of children and older people. Our main aim is to assess the extent to which household structure differs between the "old" and "new" Member States of the European Union. We find that most of the Eastern European countries may be thought of as lying on the same North-North-Western-Southern continuum defined for the "old" EU Member States, and constituting an "extreme form" of the Southern European model of living arrangements, which we term the "Eastern" model. However, the Baltic states do not fit easily onto this continuum.
\end{abstract}

\footnotetext{
${ }^{1}$ Institute for Social and Economic Research, Essex University, Wivenhoe Park, Colchester, Essex CO4 3SQ. E-mail:maria@essex.ac.uk.

${ }^{2}$ Institute for Social and Economic Research, Essex University, Wivenhoe Park, Colchester, Essex CO4 3SQ.
} 


\section{Introduction}

This paper maps variations in household structure across the countries of the newly enlarged European Union, and assesses similarities and differences between household structure in the new Member States and those observed elsewhere in the EU.

Household structures across the pre-enlargement EU-15 have been extensively documented (Andersson 2002; Robson and Berthoud 2003; Iacovou 2004; Tomassini et al. 2004 and many others). A number of studies have also included one or more Eastern European countries (Keilman 1987; Hantrais, Philipov, and Billari 2006; Gerber 2009; Hoem et al. 2009), but these analyses were based on surveys such as the Family and Fertility survey and the Gender and Generations survey, which include only a limited subset of the new EU Member States. A smaller number of studies have covered most or all of the countries of the enlarged EU: Mandic (2008) dealt with home-leaving; Liefbroer and Fokkema (2008) looked at fertility; Saraceno (2008) provided an overview of household structure in a number of different age groups, as well as some statistics on labour market status and time use; and Fokkema and Liefbroer (2008) examined trends in living arrangements between 1987 and 2002.

We build on this work by presenting detailed household-level indicators of living arrangements, and providing a close examination of specific living arrangements, including extended-family structures, which differ widely across Europe. Our paper is based on the 2008 European Union Statistics on Income and Living Conditions (EUSILC), which at the time of writing covers all countries of the expanded European Union, except for Malta. Being a general-purpose data set, the EU-SILC does not allow for the detailed investigation of family formation patterns that some other data sets provide. However, its strength lies in the scope of its coverage, which makes it possible to draw comparisons of many aspects of family structure over almost the entire postenlargement European Union. We therefore believe that this paper provides a unique resource.

A primary focus of our study is assessing whether it is possible to integrate the (predominantly Eastern European) new Member States into typologies of family structure currently in use for the countries of Western Europe, or whether behaviour in some or all of these countries differs so substantially from behaviour elsewhere in the "old" Member States that it is necessary to think in terms of an expanded typology.

The work of Hajnal $(1965,1982)$ has suggested that household structures may indeed differ systematically between "old" and "new" EU Member States. Hajnal noted an east-west division in European family formation patterns: specifically, that the regions east of a line from St. Petersburg to Trieste have historically been characterised by relatively early and near-universal marriage and a high percentage of "joint" households; while the regions to the west of the line have been characterised by later 
marriage, a higher proportion of individuals remaining unmarried, and a predominance of "simple" households. Of the 11 new Member States we consider, two (Estonia and the Czech Republic) lie on the Hajnal line, but with most of their area lying to the west of the line; four (Latvia, Lithuania, Poland, and Slovenia) lie on the Hajnal line; and five (Slovakia, Hungary, Romania, Bulgaria, and Cyprus) lie to the east of the line. Of the "old" EU countries, only Greece and Southern Italy lie to the east of the Hajnal line. The work of Hajnal refers to a preindustrial household formation system, but may still form an interesting basis for analysis today: some of the characteristics of Hajnal's divide are still evident, as the mean age at marriage in Eastern Europe is still considerably lower than in Western Europe (Kalmijn 2007), and stark differences remain in the incidence of complex households (both extended and multiple households) between the two regions (Saraceno 2008).

Because there is a great deal of heterogeneity within the "old" EU Member States, we group the EU-15 countries using a threefold typology proposed by Iacovou (2004). This typology draws on the work of Reher (1998), who found evidence of stronger family ties and higher levels of inter-generational co-residence in Southern than in Northern Europe; and on Esping-Andersen's (1990 and 1999) typology of welfare regimes.

The first group in our typology is a "Nordic" cluster consisting of the Scandinavian countries (Sweden, Denmark, and Finland) plus the Netherlands. The countries in this group are characterised by small households (particularly single-adult and lone-parent households), early residential independence for young people, and extended residential independence for elderly people; as well as an almost complete absence of the extended family. The second group, which we term the "North-Western" cluster, consists of the UK, France, Germany, Austria, Belgium, Luxembourg, and Ireland. On many indicators, these countries occupy an intermediate position between the other two groups. The third group, which we term the "Southern" cluster, consists of Italy, Spain, Portugal, and Greece. These countries are characterised by extended coresidence of parents and their adult children, and of elderly people with their adult offspring; these arrangements, together with a much lower incidence of lone-parent families, make for considerably larger household sizes.

Clearly, not all countries fall neatly into one or other of these groups. Where there are intermediate cases, we have positioned them on the edge of a group. The Netherlands is, for example, empirically speaking in some respects closer to our NorthWestern cluster than the Nordic cluster, and has been placed on the boundary between the Nordic and North-Western groups. Ireland has been placed on the boundary between the North-Western group (where it belongs geographically) and the Southern group (with which it shares a large number of features). Meanwhile, Cyprus has been 
placed on the boundary between the Southern group (with which it has clear geographical and cultural commonalities) and the other new EU members.

\section{Data and methodology}

\subsection{Data}

All analysis in this paper is based on data from the European Union Statistics on Income and Living Conditions (EU-SILC). This is an annual household survey which provides micro-level data on a number of indicators, including income, poverty, social exclusion, and living conditions.

In most countries, the sample design takes the form of a rotational panel: the sample is divided into sub-panels, each sub-panel is retained in the sample for a maximum of four years, and each year one sub-panel is dropped, to be replaced by a new replication. The exceptions are France (nine-year panel), Luxembourg, and Sweden (pure panels). Cross-sectional and longitudinal data sets are released separately; for the analysis in this paper, we use data from version 2008-1 of the crosssectional SILC, except for France, where we use data from version 2007-2, because data from the later release are not yet available. No data from Malta are currently available.

It should be noted that these data relate to private households, and that people living in institutional settings (hospitals, old people's homes, and student accommodation) are not sampled. In all countries, a large majority of individuals live in private households, but a substantial proportion of certain groups live in institutional settings: most notably, older people, students, and younger men engaged in military service. Iacovou and Skew (2010) attempted to quantify the problems arising from this issue in relation to young adults. They found that, for this group, the degree of error is likely to be relatively small. However, the proportion of elderly people omitted from the survey is likely to be larger, and to differ between regions, with shares being particularly large in the North-Western and Nordic groups of countries. Estimates of institutionalisation of the elderly indicate that in these regions, between $3 \%$ and $9 \%$ of those aged 65 and older live in institutions; among the institutionalized, women and the extreme elderly will be overrepresented (Kinsella and Wan He 2009). Table 5, and columns 3 and 5 of Table 1, are likely to be most affected by this omission. The reader should therefore bear in mind that all figures in this paper refer to the noninstitutionalised population. 


\subsection{Relationships between household members}

In using large data sets for the analysis of living arrangements, it is necessary to establish the nature of the kinship or other relationships between household members. Most household-level data sets collect this information in the form of a household grid. Unfortunately, the EU-SILC does not collect a full household grid, and instead provides information only on the identities of the spouse, partner, mother, and father of sample members of all ages. This information enables us to identify which people are living as part of a couple, and/or with their children or parents. However, many relationships cannot be identified; for example, we are almost always unable to distinguish a coresident cousin from a friend or lodger. There is also a degree of uncertainty relating to the parent/child relationship; namely, that it is not always possible to distinguish between biological or adoptive parents and stepparents. This issue arises because the "mother" and "father" identifiers have not been applied consistently in the EU-SILC: in some cases they have been used exclusively to indicate biological or adoptive parents, while in others they have also been used to indicate stepparents.

These limitations have implications for the way in which we present our findings, such as in how we define the extended family. We discuss these issues at appropriate points in the paper. In spite of these limitations, the EU-SILC does make it possible to conduct some extensive and interesting analyses of household structure, and it remains a useful — and, in many respects, a unique — source of data.

\subsection{Methodology}

The analysis in this paper is descriptive. The tables in Sections 3-5 present means over the populations of interest, and compare them between countries. All country means are weighted using the cross-sectional weights supplied with EU-SILC in order to make the sample representative of each country's population of private households.

All of the tables also present means across groups of countries: the Nordic, NorthWestern, and Southern clusters referred to in Section 1; the 15 "old" Member States (EU-15 in the tables); the 11 "new" Member States (NMS); and the mean across all countries (referred to here as EU-27, although Malta is not represented). In calculating these group averages, we adjust the cross-sectional weights by a factor reflecting each country's population, which means that each country is represented in these averages according to its total population.

In the analysis of household forms, either the household, or the individual within the household, may be considered as the unit of analysis. We combine these approaches: Tables 1 and 3 take the household as the unit of analysis, tabulating the 
percentage of households falling into different types, while Table 2 and Tables 4 and 5 take the individual as the unit of analysis, providing a more detailed picture of living arrangements for groups of particular interest.

All results are based on our own analysis of the EU-SILC data; we therefore do not repeat this information in notes to tables.

\section{Household composition}

In this section, we discuss household composition at its broadest level. The first column of Table 1 shows how household size varies across the EU: it ranges from under two in Denmark to almost three in Bulgaria. In general, households in the new Member States are far larger than elsewhere. The average household size in the new Member States is 2.8, and in all but one of the new Member States, the household size is above 2.5. Meanwhile, in the old EU-15 countries, the average household size is 2.3, and the household size in all but four countries is below 2.5. Based on these numbers, we might assume that households in the new Member States are more often complex households than in the old EU-15 countries. In fact, as was highlighted by Burch (1970) and Laslett (1972), mean household size may depend on many factors, and the age structure of the population may be as important as the complexity of family living in determining average household size.

However, an examination of extended family households (discussed further below) does indeed indicate a higher incidence of such households in many of the countries of Eastern Europe, where we also see the largest household sizes. Yet we also see, in the case of Cyprus, an example of a large household size that does not appear to arise as a result of the complexity of the households.

The remaining columns in Table 1 show the proportions of households falling into 10 types. The classification we use broadly follows that of the UN (United Nations 2007), which distinguishes one-person households (columns 2-3 in Table 1), nuclear households (columns 4-9), extended households (column 10), and composite households (which we refer to as "other" households, column 11). Within single-person and couple-only households, we separately identify households in which one or more members are aged 65 or over, as outlined in more detailed typologies used by the UN (United Nations 2006) and the European Union (Eurostat 2008). Due to the deficiencies in the EU-SILC household grid discussed above, we are unable to implement the UN classification closely in columns 9 and 10, which relate to extended families and composite or 'other' households. We describe the alternative classification we have used at the appropriate point below. 
Table 1: Household composition (columns 2-11 contain row percentages and sum to $100 \%)$

\begin{tabular}{|c|c|c|c|c|c|c|c|c|c|c|c|}
\hline & $\begin{array}{c}\text { (1) } \\
\text { Mean } \\
\text { household } \\
\text { size }\end{array}$ & $\begin{array}{c}(2) \\
\text { Single } \\
\text { person } \\
\text { under } \\
65\end{array}$ & $\begin{array}{c}(3) \\
\text { Single } \\
\text { person } \\
65+\end{array}$ & $\begin{array}{c}\text { (4) } \\
\text { Couple } \\
\text { only, } \\
\text { both } \\
\text { under } \\
65\end{array}$ & $\begin{array}{c}\text { (5) } \\
\text { Couple } \\
\text { only, at } \\
\text { least } \\
\text { one } 65+\end{array}$ & $\begin{array}{c}\text { (6) } \\
\text { Couple } \\
\text { with } \\
\text { minor } \\
\text { child(ren) }\end{array}$ & $\begin{array}{c}\text { (7) } \\
\text { Couple } \\
\text { with adult } \\
\text { child(ren) }\end{array}$ & $\begin{array}{c}\text { (8) } \\
\text { Lone } \\
\text { parent } \\
\text { with } \\
\text { minor } \\
\text { child(ren) }\end{array}$ & $\begin{array}{c}\text { (9) } \\
\text { Single } \\
\text { person } \\
\text { with adult } \\
\text { child(ren) }\end{array}$ & $\begin{array}{c}(10) \\
\text { Extended } \\
\text { family }\end{array}$ & $\begin{array}{l}\text { (11) } \\
\text { Other }\end{array}$ \\
\hline Sweden & 2.1 & 23.2 & 14.7 & 17.1 & 12.2 & 21.1 & 3.6 & 5.0 & 2.1 & 0.2 & 0.9 \\
\hline Finland & 2.1 & 25.3 & 14.0 & 20.1 & 9.7 & 19.7 & 3.9 & 3.8 & 2.1 & 0.6 & 0.9 \\
\hline Denmark & 2.0 & 31.4 & 14.4 & 15.9 & 9.8 & 18.9 & 1.9 & 4.9 & 1.5 & 0.1 & 1.4 \\
\hline Netherlands & 2.3 & 23.9 & 11.6 & 16.3 & 11.3 & 22.3 & 6.6 & 3.0 & 2.0 & 0.1 & 2.8 \\
\hline Nordic average & 2.2 & 25.2 & 13.2 & 17.0 & 11.1 & 21.0 & 4.7 & 3.9 & 1.9 & 0.2 & 1.8 \\
\hline UK & 2.4 & 16.0 & 14.0 & 16.4 & 10.5 & 22.5 & 6.8 & 5.8 & 3.4 & 1.3 & 3.3 \\
\hline France & 2.3 & 20.0 & 14.2 & 15.8 & 11.2 & 22.2 & 6.2 & 4.1 & 3.2 & 1.0 & 2.1 \\
\hline Germany & 2.1 & 25.9 & 13.3 & 14.3 & 14.5 & 16.6 & 7.1 & 3.6 & 3.2 & 0.3 & 1.3 \\
\hline Austria & 2.3 & 22.0 & 13.4 & 12.4 & 10.2 & 20.1 & 8.8 & 3.7 & 3.6 & 3.2 & 2.6 \\
\hline Belgium & 2.3 & 21.2 & 13.6 & 15.7 & 10.7 & 19.2 & 7.9 & 4.5 & 3.4 & 1.1 & 2.9 \\
\hline Luxembourg & 2.5 & 18.5 & 10.4 & 13.6 & 10.6 & 27.4 & 11.1 & 2.7 & 2.5 & 1.9 & 1.3 \\
\hline Ireland & 2.8 & 12.0 & 9.7 & 10.3 & 7.8 & 28.2 & 7.9 & 8.4 & 7.4 & 1.9 & 6.5 \\
\hline North-Western avg. & 2.2 & 21.2 & 13.7 & 15.2 & 12.2 & 20.0 & 6.9 & 4.4 & 3.3 & 0.9 & 2.2 \\
\hline Italy & 2.4 & 14.6 & 15.2 & 8.1 & 11.2 & 22.0 & 14.6 & 2.6 & 6.2 & 2.6 & 2.8 \\
\hline Spain & 2.7 & 9.2 & 8.8 & 12.2 & 9.5 & 26.6 & 16.7 & 1.4 & 6.1 & 4.5 & 5.1 \\
\hline Portugal & 2.7 & 6.3 & 11.2 & 9.5 & 12.2 & 25.4 & 15.8 & 2.7 & 7.1 & 5.5 & 4.4 \\
\hline Greece & 2.7 & 10.7 & 9.4 & 8.7 & 12.2 & 24.8 & 19.1 & 1.0 & 6.6 & 3.9 & 3.6 \\
\hline Southern average & 2.6 & 11.8 & 12.2 & 9.7 & 10.8 & 24.1 & 15.8 & 2.1 & 6.2 & 3.6 & 3.8 \\
\hline Cyprus & 2.9 & 8.7 & 7.3 & 9.4 & 11.4 & 31.5 & 17.2 & 3.3 & 4.3 & 2.7 & 4.2 \\
\hline Czech Republic & 2.5 & 12.8 & 12.1 & 13.8 & 10.0 & 22.3 & 13.0 & 3.5 & 6.7 & 4.2 & 1.8 \\
\hline Hungary & 2.6 & 11.7 & 12.5 & 11.8 & 8.4 & 21.5 & 11.6 & 3.8 & 7.9 & 7.3 & 3.7 \\
\hline Estonia & 2.3 & 19.0 & 15.4 & 11.5 & 7.9 & 18.6 & 8.3 & 4.5 & 7.8 & 5.1 & 1.9 \\
\hline Latvia & 2.6 & 13.5 & 13.2 & 8.0 & 6.2 & 17.4 & 10.1 & 4.4 & 9.1 & 12.1 & 6.1 \\
\hline Lithuania & 2.6 & 11.8 & 14.1 & 9.1 & 8.7 & 22.1 & 12.0 & 4.5 & 6.4 & 8.0 & 3.4 \\
\hline Slovenia & 2.8 & 9.7 & 11.2 & 7.3 & 9.9 & 23.6 & 19.3 & 2.5 & 7.3 & 6.7 & 2.5 \\
\hline Slovakia & 2.9 & 10.9 & 13.2 & 7.6 & 7.8 & 21.5 & 17.8 & 2.2 & 7.0 & 8.5 & 3.5 \\
\hline Poland & 2.8 & 11.6 & 13.1 & 10.3 & 6.7 & 23.0 & 14.1 & 2.1 & 6.1 & 10.8 & 2.3 \\
\hline Bulgaria & 2.9 & 6.4 & 11.9 & 9.3 & 10.8 & 15.1 & 14.7 & 1.5 & 6.7 & 19.7 & 3.8 \\
\hline Romania & 2.9 & 9.1 & 12.7 & 10.2 & 9.6 & 20.7 & 13.7 & 1.2 & 4.6 & 12.6 & 5.7 \\
\hline NMS average & 2.8 & 10.9 & 12.8 & 10.5 & 8.3 & 21.5 & 13.7 & 2.4 & 6.2 & 10.3 & 3.4 \\
\hline EU-15 average & 2.3 & 18.9 & 13.2 & 13.8 & 11.7 & 21.3 & 9.3 & 3.7 & 4.0 & 1.6 & 2.6 \\
\hline EU-27 average & 2.4 & 17.5 & 13.1 & 13.2 & 11.1 & 21.3 & 10.1 & 3.5 & 4.4 & 3.2 & 2.8 \\
\hline
\end{tabular}

Notes: In this table, bold type denotes the five countries with the highest incidence of each situation, and italics denote the five countries with the lowest incidence of each situation. Minor children are defined as children under 18 years old. Households with minor children (columns 6 and 8 ) may also contain adult children.

We start by considering single-adult households in which the adult is under age 65 (column 2). These constitute $17.5 \%$ of households across the EU, with the share ranging from $6 \%$ in Portugal and Bulgaria to $31 \%$ in Denmark. In general, the proportion of single-adult households is much lower in the Southern and Eastern European countries than in the North-Western and (particularly) the Nordic group. Regional variations in the percentage of couple-only households, in which both adults 
are under age 65, follow the same pattern (column 4), though the differences are less pronounced, with percentages ranging from $7 \%$ in Slovenia to $20 \%$ in Finland.

We turn now to households in which at least one adult is aged 65 or over. The distribution of these household types does not neatly follow our country groupings. This is to be expected, since many factors contribute to household composition among older people, including the typical age differences between partners, the differences in life expectancy between men and women, the rates of divorce and separation, and whether the elderly tend to choose to live with adult children or other relatives. Single-adult households among the 65+ age group (column 3) are most common in Estonia and Italy $(15 \%)$ and least common in Cyprus (7\%); couple households among this age group are most common in Germany (15\%) and least common in Latvia (6\%).

Columns 6-9 relate to nuclear family households. In a manner similar to that of the UN typology, we make the distinction between households headed by a couple ${ }^{3}$ (columns 6 and 7) (though we do not distinguish between married and cohabiting couples), and by a lone parent (columns 8 and 9). We also distinguish between households containing minor children, with minor children being defined as children under the age of 18 (although adult children may also be living in the household); and households containing only adult children. The most common of these four household types is that of a couple with minor children (column 6). These arrangements account for $21 \%$ of households across the EU. There are no systematic regional differences, but there are differences between countries: couples with minor children account for only $15 \%$ of households in Bulgaria, but for over $31 \%$ of households in Cyprus. By contrast, there are huge regional differences in the proportion of households consisting of a couple with adult children (column 7). These account for under 5\% of all households in the Nordic cluster, but for $14 \%$ of households in the new Member States, and for $16 \%$ of households in the Southern countries. This reflects the much later age at homeleaving in these countries (Mandic 2008).

Lone parents with minor children (column 8 ) account for only $3.5 \%$ of all households across the EU. The proportions of such households are higher in the Nordic and North-Western clusters; however, the more interesting variations are between countries rather than groups of countries. Only 1\% of households in Greece and Romania consist of a lone parent with minor children, compared with over $8 \%$ of households in Ireland ${ }^{4}$ and $5 \%$ in the UK and Sweden. These figures should not, however, be taken as indicative of the level of lone parenthood across countries of the

\footnotetext{
${ }^{3}$ These include households in which both members of the couple are the adoptive or biological parents of the children, as well as stepfamilies.

${ }^{4}$ Several other studies (e.g., Chambaz 2001; UNICEF 2001) have reported a high incidence of lone parenthood in Ireland. However, our estimate that $8 \%$ of Irish households consist of a lone parent plus minor child may be around two percentage points too high, as the Irish Census (Central Statistics Office Ireland 2007) recorded around $10.5 \%$ of households consisting of a lone parent plus a child of any age.
} 
EU, since in Southern and Eastern Europe lone parents are more likely to live in extended-family households rather than in single units. Single people living with adult offspring (column 9) account for 4.4\% of households across the EU, and these arrangements are most common in the Southern and Eastern clusters. These households are particularly common in areas in which both delayed home-leaving and marital separation are commonplace; this is the case in Ireland, Hungary, Estonia, and Slovenia, where these households account for over 7\% of the total, and particularly in Latvia, where they account for $9 \%$ of the total.

Column 10 represents extended-family households. Conventionally, these are taken to be households containing (at least) one family nucleus ${ }^{5}$, plus one or more relatives other than unmarried offspring. Unfortunately, in the EU-SILC data the only relationships identified are maternal or paternal and marital or cohabitating relationships. This allows us to identify extended family households, such as those containing a nuclear family (with or without children), plus a grandparent(s) ${ }^{6}$. However, we are unable to distinguish between households in which siblings, aunts or uncles, etc., live together in an extended-family situation; and households in which unrelated individuals are sharing accommodation (eg as flatmates or lodgers). Thus, some extended families will have been placed in the "other" category (column 11). In terms of the proportion of households in each country that are extended-family households, we may think of column 10 as providing a lower bound to this estimate, and the combination of column 10 plus column 11 as providing an upper bound.

This issue notwithstanding, enormous regional differences may be observed in the prevalence of extended-family households. They are virtually absent in the Nordic cluster, representing only $0.2 \%$ of households; and are also very uncommon in the North-Western cluster, where they account for only $0.9 \%$ of households. They are more common in Southern Europe and the new Member States, where they account for 3.6\% and $10.3 \%$ of households, respectively. In Bulgaria, extended families represent almost $20 \%$ of households, which means that there are huge inter-country differences in this category: extended-family households are almost 200 times more common in Bulgaria than in Denmark or the Netherlands.

\footnotetext{
${ }^{5}$ The household typology suggested by Hammel and Laslett (1974) separately distinguishes extended families containing more than one family nucleus as 'multiple family households'; in the UN typology (United Nations 2007), an extended family can contain more than one family nucleus.

${ }^{6}$ In some cases these households contain other adults or children. In the UN typology, these households would be defined as composite households, but we include these households along with extended-family households.
} 


\subsection{Living alone}

In Table 1, a great deal of between-country variation is evident in the proportions of single-person households. Because these variations are so large, and because singleperson households are important from the perspective of policy, as they are associated with a disproportionate risk of poverty among the elderly (Smeeding and Sandström 2005) and the young (Iacovou and Berthoud 2001), we devote this section to examining these differences.

Table 2 is divided into two panels, with the left-hand panel relating to men, and the right-hand panel relating to women. In each panel, the first column shows the percentages of men and women aged 18 and over who live alone (these figures differ from columns 2 and 3 of Table 1, which show the proportions of households that are composed of individuals living alone). The percentage of men who live alone ranges from $5 \%$ in Portugal to $30 \%$ in Denmark, while the percentage of women who live alone ranges from $8 \%$ in Cyprus to 30\% in Denmark. Regional differentials are marked, with living alone being most common in the Nordic group of countries, followed quite closely by the North-Western cluster; but considerably less common in the Southern countries, and even less so in the new Member States, where only 7\% of men and 13\% of women are to be found living alone.

The remaining columns of Table 2 show the percentages of men and women in different age groups living alone in each country: we show these percentages for people aged 20-29, 30-49, 50-69, 70-79, and 80+. For reasons of space, some of these bands are wider than others, and people aged 18 and 19 are omitted from this section of the table altogether, as even in the Nordic countries, only a small minority of people under age 20 live alone.

In all countries, more people live alone at the oldest ages (70-79, and particularly $80+)$ than at younger ages. This has to do with widowhood: women, with their longer life expectancy (see Appendix), are around twice as likely to live alone at the oldest ages as men. The fact that a much higher proportion of older people live alone in the Nordic and North-Western clusters than in the Southern countries and the new Member States is attributable to the relative rarity of extended-family living in these countries.

In the Nordic countries, another peak in solo living is visible at the other end of the age spectrum: in these countries, $29 \%$ of men and $27 \%$ of women in their twenties live alone. These levels are about twice as high as the percentages of people in their twenties living alone in the North-Western countries, and many times higher than the percentages living alone in the Southern countries and the new Member States, where (with the exception of Estonia) solo living is extremely uncommon among this young age group. 
Table 2: $\quad$ Percentages living alone, by sex and by age group

\begin{tabular}{|c|c|c|c|c|c|c|c|c|c|c|c|c|}
\hline & \multicolumn{6}{|c|}{ Men } & \multicolumn{6}{|c|}{ Women } \\
\hline & $\begin{array}{c}\text { All } \\
\text { men }\end{array}$ & $\begin{array}{l}\text { Aged } \\
20-29\end{array}$ & $\begin{array}{l}\text { Aged } \\
30-49\end{array}$ & $\begin{array}{l}\text { Aged } \\
50-69\end{array}$ & $\begin{array}{l}\text { Aged } \\
70-79\end{array}$ & $\begin{array}{l}\text { Aged } \\
80+\end{array}$ & $\begin{array}{c}\text { All } \\
\text { women }\end{array}$ & $\begin{array}{l}\text { Aged } \\
20-29\end{array}$ & $\begin{array}{l}\text { Aged } \\
30-49\end{array}$ & $\begin{array}{l}\text { Aged } \\
50-69\end{array}$ & $\begin{array}{l}\text { Aged } \\
70-79\end{array}$ & $\begin{array}{c}\text { Aged } \\
80+\end{array}$ \\
\hline Sweden & 21.1 & 36.1 & 17.2 & 16.8 & 20.9 & 40.5 & 24.0 & 25.1 & 8.1 & 23.6 & 43.4 & 76.1 \\
\hline Finland & 21.0 & 27.4 & 18.5 & 20.7 & 21.6 & 32.4 & 25.9 & 21.9 & 11.9 & 26.7 & 47.1 & 69.8 \\
\hline Denmark & 29.6 & 46.2 & 25.8 & 27.4 & 30.8 & 37.0 & 29.6 & 40.5 & 9.7 & 31.7 & 55.8 & 78.1 \\
\hline Netherlands & 18.6 & 20.6 & 20.8 & 15.8 & 14.6 & 36.1 & 21.6 & 24.7 & 10.7 & 18.3 & 44.3 & 76.2 \\
\hline Nordic average & 21.2 & 29.2 & 20.4 & 18.6 & 19.8 & 37.1 & 24.1 & 26.6 & 10.1 & 23.0 & 46.4 & 75.4 \\
\hline UK & 15.0 & 7.0 & 14.0 & 16.3 & 23.1 & 44.2 & 17.3 & 4.3 & 7.1 & 19.4 & 44.4 & 68.8 \\
\hline France & 16.5 & 20.8 & 14.5 & 15.3 & 19.8 & 29.3 & 21.5 & 16.3 & 9.1 & 22.1 & 43.5 & 64.1 \\
\hline Germany & 21.4 & 15.2 & 22.1 & 24.4 & 20.9 & 36.6 & 24.2 & 19.7 & 15.2 & 29.4 & 43.6 & 52.8 \\
\hline Austria & 16.7 & 16.2 & 16.3 & 18.2 & 13.8 & 29.4 & 20.8 & 11.5 & 10.8 & 22.8 & 44.8 & 59.4 \\
\hline Belgium & 18.3 & 13.3 & 18.9 & 20.0 & 20.4 & 33.1 & 19.6 & 10.1 & 9.7 & 19.9 & 39.8 & 67.5 \\
\hline Luxembourg & 13.4 & 8.6 & 15.6 & 11.8 & 20.4 & 15.9 & 16.4 & 9.7 & 8.6 & 18.8 & 39.9 & 57.0 \\
\hline Ireland & 10.0 & 3.1 & 8.5 & 13.7 & 23.4 & 32.4 & 11.0 & 4.3 & 3.9 & 12.7 & 37.6 & 54.0 \\
\hline North-Western avg. & 17.9 & 14.4 & 17.3 & 19.4 & 21.0 & 36.0 & 21.1 & 13.6 & 10.8 & 24.2 & 43.5 & 63.2 \\
\hline Italy & 12.4 & 7.5 & 13.1 & 11.9 & 15.5 & 22.4 & 17.1 & 5.1 & 8.0 & 13.5 & 37.8 & 56.9 \\
\hline Spain & 7.3 & 5.8 & 7.6 & 6.0 & 9.7 & 16.6 & 8.6 & 2.5 & 3.5 & 7.0 & 24.6 & 37.3 \\
\hline Portugal & 5.0 & 1.5 & 4.3 & 4.2 & 12.7 & 17.9 & 10.3 & 3.7 & 1.3 & 10.5 & 30.8 & 41.8 \\
\hline Greece & 6.5 & 9.7 & 6.5 & 3.8 & 6.3 & 13.9 & 11.6 & 11.0 & 3.7 & 9.8 & 27.7 & 39.4 \\
\hline Southern average & 9.4 & 6.5 & 9.8 & 8.5 & 12.6 & 19.4 & 13.0 & 4.5 & 5.4 & 10.7 & 32.0 & 48.7 \\
\hline Cyprus & 6.0 & 4.6 & 6.6 & 4.4 & 11.8 & 16.6 & 8.0 & 2.5 & 2.7 & 9.3 & 31.2 & 38.7 \\
\hline Czech Republic & 9.8 & 6.5 & 8.8 & 10.9 & 17.1 & 27.3 & 14.1 & 3.9 & 2.9 & 16.8 & 46.1 & 57.4 \\
\hline Hungary & 7.8 & 4.7 & 5.7 & 9.4 & 15.5 & 27.4 & 14.7 & 4.0 & 3.2 & 18.2 & 42.9 & 48.6 \\
\hline Estonia & 14.8 & 16.3 & 12.1 & 15.9 & 21.6 & 32.1 & 21.6 & 9.5 & 9.2 & 25.5 & 48.6 & 56.3 \\
\hline Latvia & 9.4 & 4.4 & 7.3 & 13.7 & 18.7 & 28.2 & 14.8 & 4.0 & 4.3 & 19.7 & 36.8 & 43.0 \\
\hline Lithuania & 8.0 & 5.0 & 5.9 & 10.3 & 17.6 & 25.3 & 15.8 & 5.9 & 4.2 & 19.3 & 45.3 & 46.8 \\
\hline Slovenia & 6.4 & 2.7 & 6.0 & 8.5 & 9.0 & 17.3 & 11.6 & 1.8 & 2.9 & 11.5 & 37.0 & 51.3 \\
\hline Slovakia & 5.4 & 2.6 & 4.1 & 6.3 & 15.6 & 20.3 & 14.3 & 1.4 & 3.2 & 19.8 & 46.9 & 52.1 \\
\hline Poland & 7.2 & 3.2 & 4.5 & 9.9 & 18.6 & 30.6 & 13.9 & 3.5 & 3.7 & 16.6 & 42.8 & 52.9 \\
\hline Bulgaria & 5.4 & 1.1 & 3.3 & 6.3 & 11.8 & 26.9 & 9.4 & 0.7 & 1.1 & 9.5 & 28.8 & 45.0 \\
\hline Romania & 6.7 & 2.7 & 3.9 & 9.6 & 15.3 & 26.0 & 11.8 & 1.9 & 2.6 & 14.7 & 38.7 & 45.9 \\
\hline NMS average & 7.3 & 3.6 & 5.1 & 9.5 & 16.4 & 27.6 & 13.4 & 3.1 & 3.2 & 16.2 & 41.1 & 50.3 \\
\hline EU-15 average & 13.4 & 3.1 & 3.2 & 16.2 & 41.1 & 50.3 & 18.7 & 11.9 & 9.0 & 19.9 & 39.6 & 58.4 \\
\hline EU-27 average & 13.8 & 10.7 & 13.0 & 14.7 & 17.8 & 29.4 & 17.6 & 9.8 & 7.8 & 19.1 & 40.0 & 56.9 \\
\hline
\end{tabular}

Notes: In this table, bold type denotes the five countries with the highest incidence, and italics denote the five countries with the lowest incidence of each situation. The percentages in the "All men" and "All women" columns refer to men and women aged 18 and over.

Gender differences in the proportions living alone in the youngest age group are very small indeed, but large differences can be observed between men and women in their thirties and forties. We attribute this to divorce and separation: when a couple has children, they are much more likely to live with their mother than with their father after separation, which means that men in their thirties and forties are about twice as likely as women to live alone. Again, these gender differences are overlaid by differences between regions, with solo living being more common in the North-Western and (particularly) the Nordic countries 
When men and women reach their fifties and sixties, this gender gap begins to close: at these ages, the differential effect of children remaining with their mothers following separation is reduced as children increasingly leave home, and begins to be outweighed by the effects of women's longer life expectancy. Thus, in all groups of countries, women at these ages are slightly (though not much) more likely than men to be living alone.

\subsection{The extended family}

Table 1 revealed substantial regional differences in the prevalence of extended-family living. In this section, we examine this phenomenon in greater detail. The first column of Table 3 replicates column 10 of Table 1, showing the percentages of extended-family households in each country. Columns 2-4 give more detailed information on household composition, showing the percentage of extended-family households that are (a) twogenerational households consisting of a couple plus one or more of their parents; (b) three-generational households consisting of a single [unpartnerned] adult, plus one or more of their children, plus one or more of their parents; and (c) three-generational households consisting of a couple, plus one or more of their children, plus one or more of their parents. The final column shows the number of extended-family households in each country. It should be noted that these numbers are very small in the Nordic and some of the North-Western countries, and that results in these countries should be treated as indicative only.

Again, clear regional differences emerge. In the Scandinavian countries, the small number of extended-family households mostly consist of adult children living with a partner and one (or both) of their parents. In the Southern and Eastern European countries, by contrast, extended-family households predominantly consist of multigenerational households in which a couple live with both parents and children. In the North-Western countries, we see a larger degree of heterogeneity than in other clusters. In the UK and Ireland, the most common extended-family form is a three-generational household formed of a lone parent living with one or both of her own parents. In Austria and Luxembourg, a three-generational extended form is again the most common, although in these countries, couples rather than lone parents tend to be the middle generation. In the rest of the cluster, extended family types are distributed more or less evenly across the three types of household. 
Table 3: Characteristics of extended-family households

\begin{tabular}{|c|c|c|c|c|c|}
\hline & $\begin{array}{c}\text { (1) } \\
\text { Extended- } \\
\text { family } \\
\text { households }\end{array}$ & $\begin{array}{c}\text { (2) } \\
\text { Couple } \\
\text { with } \\
\text { parent(s) }\end{array}$ & $\begin{array}{l}\text { (3) } \\
\text { Single adult with } \\
\text { parent(s) plus } \\
\text { child(ren) }\end{array}$ & $\begin{array}{c}\text { (4) } \\
\text { Couple with } \\
\text { parent(s) and } \\
\text { child(ren) }\end{array}$ & $\begin{array}{c}\text { (5) } \\
\text { Unweighted } \mathbf{N}\end{array}$ \\
\hline Sweden & 0.2 & 62.1 & 25.0 & 12.9 & 36 \\
\hline Finland & 0.6 & 66.2 & 9.9 & 23.9 & 89 \\
\hline Denmark & 0.1 & 70.2 & 27.0 & 2.9 & 17 \\
\hline Netherlands & 0.1 & 19.2 & 63.2 & 17.6 & 14 \\
\hline Nordic average & 0.2 & 52.2 & 29.4 & 18.4 & - \\
\hline UK & 1.3 & 20.8 & 57.8 & 21.4 & 100 \\
\hline France & 1.0 & 33.2 & 29.0 & 37.8 & 100 \\
\hline Germany & 0.3 & 28.5 & 36.4 & 35.1 & 62 \\
\hline Austria & 3.2 & 24.4 & 18.4 & 57.2 & 157 \\
\hline Belgium & 1.1 & 34.2 & 26.8 & 39.0 & 75 \\
\hline Luxembourg & 1.9 & 18.7 & 30.2 & 51.1 & 97 \\
\hline Ireland & 1.9 & 5.8 & 67.6 & 26.6 & 79 \\
\hline North-Western avg. & 0.9 & 26.2 & 40.0 & 33.8 & - \\
\hline Italy & 2.6 & 20.7 & 30.4 & 48.9 & 675 \\
\hline Spain & 4.5 & 24.0 & 27.1 & 49.0 & 747 \\
\hline Portugal & 5.5 & 20.7 & 23.6 & 55.7 & 301 \\
\hline Greece & 3.9 & 19.8 & 22.8 & 57.4 & 301 \\
\hline Southern average & 3.6 & 22.0 & 27.5 & 50.5 & - \\
\hline Cyprus & 2.7 & 41.0 & 14.6 & 44.4 & 128 \\
\hline Czech Republic & 4.2 & 20.0 & 34.1 & 45.9 & 404 \\
\hline Hungary & 7.3 & 19.1 & 27.6 & 53.3 & 616 \\
\hline Estonia & 5.1 & 17.7 & 42.3 & 40.1 & 437 \\
\hline Latvia & 12.1 & 11.5 & 38.1 & 50.5 & 606 \\
\hline Lithuania & 8.0 & 11.7 & 31.4 & 56.9 & 414 \\
\hline Slovenia & 6.7 & 16.6 & 23.4 & 60.1 & 1,078 \\
\hline Slovakia & 8.5 & 16.3 & 23.7 & 60.0 & 557 \\
\hline Poland & 10.8 & 15.9 & 20.6 & 63.5 & 1,631 \\
\hline Bulgaria & 19.7 & 14.9 & 17.3 & 67.8 & 801 \\
\hline Romania & 12.6 & 18.3 & 15.3 & 66.5 & 654 \\
\hline NMS average & 10.3 & 16.6 & 21.1 & 62.3 & - \\
\hline EU-15 average & 1.6 & 23.8 & 31.7 & 44.5 & - \\
\hline EU-27 average & 3.2 & 19.6 & 25.5 & 54.9 & - \\
\hline
\end{tabular}

Note: Bold type denotes the five countries with the highest incidence of each situation, and italics denote the five countries with the lowest incidence of each situation. Each of the household types in columns 2-4 may contain additional adults or children. 
There is also a degree of heterogeneity between the countries of Eastern Europe. For a start, levels of extended-family living in some countries (particularly the Czech Republic, Estonia, and Slovenia) are relatively low, and more similar to the levels found in Southern Europe than elsewhere in Eastern Europe. Additionally, the distributions of extended-family types in Hungary and the Czech Republic look more similar to the distributions in Southern Europe than to the distributions in Eastern Europe, and the distributions in the Baltic states, particularly Estonia and Latvia, are more similar to the distributions found in other countries with high levels of lone parenthood; namely, the UK and Ireland. Thus, the Eastern European pattern characterised by a high proportion of extended-family and predominantly three-generational households is most strongly driven by a subset of countries: Latvia, Slovakia, Slovenia, Poland, Bulgaria, and Romania.

\section{Children}

In this and the following section, we focus on two groups whose living arrangements are of particular interest to social scientists: children and older people. The living arrangements of both these groups are linked to their risk of poverty, with older people living alone (Harrington Meyer 1990; Brady 2004) and children living with a lone parent (Bradshaw et al. 1996; Kilkey 2000; Fondazione G Brodolini 2007) being at disproportionate risk. In addition, children's living arrangements are related to their outcomes in later life, over and above the effect of poverty.

We deal first with children. Table 4 presents a "child's-eye" view of living arrangements. The first three columns show the proportions of children (i.e., of individuals under age 18) who live with a lone parent, with two parents who are cohabiting but not married, and with two parents who are married to each other. The final column follows on from the previous section by showing the percentage of children living in an extended-family situation. 
Table 4: The living situation of children

\begin{tabular}{|c|c|c|c|c|}
\hline & $\begin{array}{c}\text { (1) } \\
\text { Lone parent }\end{array}$ & $\begin{array}{c}(2) \\
\text { Cohabiting couple }\end{array}$ & $\begin{array}{c}(3) \\
\text { Married couple }\end{array}$ & $\begin{array}{c}(4) \\
\text { Extended family }\end{array}$ \\
\hline Sweden & 17.0 & 27.3 & 54.4 & 0.5 \\
\hline Finland & 13.4 & 16.4 & 69.2 & 0.7 \\
\hline Denmark & 17.8 & 14.0 & 66.9 & 0.1 \\
\hline Netherlands & 11.5 & 13.9 & 74.2 & 0.4 \\
\hline Nordic average & 14.2 & 17.7 & 67.2 & 0.4 \\
\hline UK & 20.8 & 12.8 & 65.1 & 3.1 \\
\hline France & 13.5 & 21.0 & 64.5 & 1.9 \\
\hline Germany & 15.1 & 6.6 & 77.5 & 0.7 \\
\hline Austria & 12.9 & 10.6 & 74.4 & 6.6 \\
\hline Belgium & 15.3 & 15.1 & 67.2 & 2.6 \\
\hline Luxembourg & 9.9 & 8.0 & 81.9 & 2.8 \\
\hline Ireland & 23.2 & 7.4 & 67.8 & 3.4 \\
\hline North-Western avg. & 16.5 & 13.3 & 69.2 & 2.1 \\
\hline Italy & 10.8 & 6.3 & 82.1 & 5.3 \\
\hline Spain & 7.1 & 7.8 & 83.9 & 5.8 \\
\hline Portugal & 12.3 & 11.0 & 74.6 & 11.1 \\
\hline Greece & 4.8 & 2.1 & 91.8 & 5.7 \\
\hline Southern average & 9.1 & 6.9 & 82.9 & 6.0 \\
\hline Cyprus & 9.3 & 0.8 & 89.0 & 2.9 \\
\hline Czech Republic & 14.9 & 9.8 & 74.6 & 7.7 \\
\hline Hungary & 15.4 & 12.2 & 71.3 & 15.2 \\
\hline Estonia & 21.4 & 22.9 & 54.0 & 11.2 \\
\hline Latvia & 23.3 & 14.5 & 58.9 & 25.1 \\
\hline Lithuania & 17.6 & 5.2 & 74.1 & 15.6 \\
\hline Slovenia & 10.0 & 19.8 & 69.6 & 13.0 \\
\hline Slovakia & 10.1 & 4.3 & 84.9 & 19.8 \\
\hline Poland & 10.8 & 10.6 & 77.9 & 22.4 \\
\hline Bulgaria & 14.4 & 15.6 & 66.9 & 44.1 \\
\hline Romania & 6.5 & 7.0 & 84.1 & 23.7 \\
\hline NMS average & 11.5 & 10.1 & 76.9 & 21.2 \\
\hline EU-15 average & 14.1 & 11.9 & 72.9 & 3.1 \\
\hline EU-27 average & 13.6 & 11.5 & 73.8 & 6.8 \\
\hline
\end{tabular}

Notes: "Children" are defined as all those under age 18. Percentages in columns $1-3$ do not sum exactly to $100 \%$ as a small proportion of children are living with adults not defined as their parents. Bold type denotes the five countries with the highest incidence of each situation, and italics denote the five countries with the lowest incidence of each situation. 
Because the EU-SILC data do not allow us to distinguish fully between biological or adoptive parents, "official" stepparents, and other co-resident partners, we have allocated children to these categories as follows. The "lone parent" category includes all children living with only one parent, where that parent does not have a co-resident partner. The "cohabiting couple" category includes children living with two parents who are cohabiting rather than married, as well as children living with one parent who is cohabiting with a partner who is not defined as the child's parent. The "married couple" category includes children living with two parents who are married, as well as children living with one parent who is married to an adult who is not defined as the child's parent. Despite these limitations, our findings are similar to those of (e.g.) Perelli-Harris et al. (2009), who covered fewer countries with more detailed data.

While we saw earlier (Table 1) that the proportion of lone-parent households is generally small, the percentage of children living with a lone parent is considerably larger, ranging from $7 \%$ or less in Greece, Spain, and Romania, to over $20 \%$ in the UK, Ireland, Estonia, and Latvia. There is a high degree of heterogeneity within regional groups, and particularly within Eastern Europe: in the Baltic republics, the rates of lone parenthood are among the highest in Europe; while in Slovenia, Slovakia, Poland, and Romania, they are among the lowest. Comparing these figures with the figures on loneparent households from Column 8 of Table 1 we see that, in general, those countries with a large proportion of lone-parent households are also the countries with a large proportion of children living with a lone parent, and vice versa. Perhaps the greatest discrepancy between the two sets of figures is in the case of Bulgaria, where a relatively high proportion of children are living with a lone parent, but only $1.5 \%$ of households are lone-parent households with minor children. This is due to the high proportion of lone parents living in extended-family households in this country; it may also be due to the fact that the average number of children in lone-parent households is high in Bulgaria.

The percentages of children living with two parents in a cohabiting union follow broadly similar patterns to those of lone parenthood, and are thus highest in the Nordic countries (particularly in Sweden, where $27 \%$ of children live with cohabiting parents) and in much of North-Western Europe. The proportions of children living with cohabiting parents are much lower in Southern Europe, and again there is a high level of heterogeneity in Eastern Europe, with only 5\% of children living with cohabiting parents in Lithuania and Slovakia, compared with 20\% in Slovenia and 23\% in Estonia.

Looking at the percentages of children living with two parents who are married, we see that over $90 \%$ of children in Greece and just short of $90 \%$ of children in Cyprus live with two married parents; the proportions are also high across the rest of Southern Europe and in Slovakia, Poland, and Romania. By contrast, only just over half of all children live with two married parents in Sweden, largely thanks to the high proportion 
whose parents are cohabiting rather than married; this is also the case in Estonia and Latvia, where high rates of lone parenthood also play a role.

Column 4 of Table 4 shows the percentages of children living in extended families. The regional differences mirror those found in previous sections, but in a more extreme way: extended-family living is rare in the Nordic and North-Western countries, where only $0.4 \%$ and $2.1 \%$ of children live in extended-family households; it is more common in the Southern countries, where $6 \%$ of children live in extended families; and it is extremely common in Eastern Europe, where one in five children lives in this type of household. Once again, there is heterogeneity within Eastern Europe: only 8\% of children live in an extended family in the Czech Republic, compared with $20 \%$ of children or more in Latvia, Slovakia, Poland, and Romania. And in Bulgaria, this proportion rises to $44 \%$, meaning that almost half of all children live in an extended family.

\section{Older people}

Table 5 shows the living arrangements of older people across the $\mathrm{EU}^{7}$. For men and women separately, we present the percentages living with a partner (columns 1 and 4). Of those who are living with a partner, we show the percentages of those living with just the partner (columns 2 and 5); for those who are not living with a partner, we show the percentages living alone (columns 3 and 6).

Looking first at the percentages living with a partner, we see that there is a large difference between men and women, with $75 \%$ of older men, but only $44 \%$ of older women, living with a partner. As discussed in Section 3.1, this arises from (a) women's higher life expectancy, and (b) the fact that men tend to be slightly older than their female partners. The percentages of men and women living with a partner do not vary greatly between the regions, except that women in the new Member States are substantially less likely than elsewhere to live with a partner (34\% for the NMS versus $47 \%$ for the EU-15). As discussed earlier, this is due in a large part to the very large gap in life expectancy between men and women in the Eastern European countries.

\footnotetext{
${ }^{7}$ It should be noted that these figures relate to older people in private households: older people in institutions such as nursing homes are not sampled by the EU-SILC, and are not included in this analysis.
} 
Iacovou \& Skew: Household composition across the new Europe: Where do the new Member States fit in?

Table 5: The living arrangements of people aged 65 years and over

\begin{tabular}{|c|c|c|c|c|c|c|}
\hline & \multicolumn{3}{|c|}{ Men aged 65+ } & \multicolumn{3}{|c|}{ Women aged $65+$} \\
\hline & $\begin{array}{c}\% \\
\text { Living } \\
\text { with a } \\
\text { partner }\end{array}$ & $\begin{array}{c}\text { \% Living with } \\
\text { just a partner } \\
\text { (of all those } \\
\text { living with a } \\
\text { partner) }\end{array}$ & $\begin{array}{c}\text { \% Living } \\
\text { alone (of all } \\
\text { those living } \\
\text { without a } \\
\text { partner) }\end{array}$ & $\begin{array}{c}\% \\
\text { Living } \\
\text { with a } \\
\text { partner }\end{array}$ & $\begin{array}{c}\text { \% Living with } \\
\text { just a partner } \\
\text { (of all those } \\
\text { living with a } \\
\text { partner) }\end{array}$ & $\begin{array}{c}\% \text { Living } \\
\text { alone (of all } \\
\text { those living } \\
\text { without a } \\
\text { partner) }\end{array}$ \\
\hline Sweden & 72.8 & 97.0 & 94.1 & 47.1 & 98.6 & 96.6 \\
\hline Finland & 71.8 & 90.6 & 85.4 & 41.1 & 91.7 & 87.8 \\
\hline Denmark & 67.5 & 98.7 & 96.2 & 41.6 & 99.2 & 97.1 \\
\hline Netherlands & 80.1 & 93.6 & 91.5 & 48.8 & 96.8 & 94.6 \\
\hline Nordic average & 74.9 & 94.9 & 92.2 & 46.0 & 96.9 & 94.4 \\
\hline UK & 69.2 & 87.3 & 87.6 & 45.6 & 90.1 & 85.5 \\
\hline France & 74.6 & 86.6 & 84.2 & 43.8 & 91.9 & 86.4 \\
\hline Germany & 75.4 & 94.0 & 93.1 & 54.8 & 96.6 & 90.9 \\
\hline Austria & 76.6 & 76.0 & 80.9 & 42.7 & 79.5 & 77.8 \\
\hline Belgium & 73.3 & 85.4 & 86.8 & 46.1 & 89.1 & 83.8 \\
\hline Luxembourg & 78.9 & 84.5 & 81.6 & 50.4 & 89.3 & 81.9 \\
\hline Ireland & 67.5 & 79.7 & 71.8 & 41.8 & 87.1 & 66.7 \\
\hline North-Western avg. & 73.6 & 89.5 & 88.5 & 48.5 & 93.0 & 86.9 \\
\hline Italy & 77.0 & 67.1 & 70.8 & 42.0 & 73.5 & 69.3 \\
\hline Spain & 80.7 & 59.3 & 56.1 & 48.3 & 64.1 & 49.3 \\
\hline Portugal & 79.0 & 72.8 & 57.7 & 46.1 & 77.5 & 56.4 \\
\hline Greece & 87.6 & 60.8 & 59.4 & 47.3 & 71.0 & 53.7 \\
\hline Southern average & 79.3 & 64.4 & 64.8 & 44.7 & 70.4 & 61.2 \\
\hline Cyprus & 84.7 & 76.5 & 68.6 & 54.3 & 82.6 & 62.6 \\
\hline Czech Republic & 77.2 & 81.5 & 77.5 & 39.2 & 86.3 & 71.0 \\
\hline Hungary & 75.9 & 75.6 & 65.5 & 30.4 & 82.0 & 59.2 \\
\hline Estonia & 72.3 & 77.1 & 79.9 & 29.5 & 79.1 & 67.3 \\
\hline Latvia & 69.3 & 58.3 & 61.4 & 26.3 & 64.0 & 49.1 \\
\hline Lithuania & 75.5 & 73.0 & 68.2 & 33.6 & 76.6 & 62.7 \\
\hline Slovenia & 83.5 & 67.4 & 58.4 & 39.0 & 72.3 & 59.2 \\
\hline Slovakia & 76.6 & 66.5 & 61.4 & 33.2 & 70.7 & 64.5 \\
\hline Poland & 70.9 & 62.2 & 65.8 & 30.3 & 67.2 & 60.5 \\
\hline Bulgaria & 76.9 & 64.4 & 58.1 & 38.6 & 67.4 & 47.9 \\
\hline Romania & 72.4 & 72.2 & 62.1 & 36.3 & 75.1 & 57.6 \\
\hline NMS average & 73.7 & 69.0 & 65.2 & 33.6 & 73.4 & 59.8 \\
\hline EU-15 average & 75.6 & 81.3 & 82.2 & 47.0 & 85.7 & 78.1 \\
\hline EU-27 average & 75.3 & 79.4 & 79.3 & 44.4 & 83.9 & 73.9 \\
\hline
\end{tabular}

Note: Bold type denotes the five countries with the highest incidence of each situation, and italics denote the five countries with the lowest incidence of each situation. 
Elsewhere in Table 5, the differences between men and women are far smaller than the differences between regions. Two "ideal types" are visible. In the Nordic cluster and in many of the North-Western countries, in particular Germany, the predominant living arrangement for older people is either with a spouse or partner, or alone. These two arrangements account for well over $90 \%$ of older people in the Nordic countries, and almost $90 \%$ in the North-Western European countries.

In Southern Europe and several of the New Member States of Eastern Europe, by contrast, it is much more common for older people (those both with and without partners) to live with others. In these groups of countries, over $30 \%$ of men and women live with other people; these figures are particularly high in Spain, Latvia, and Bulgaria. In Southern Europe and several of the New Member States of Eastern Europe, by contrast, it is much more common for older people (those both with and without partners) to live with others: in these groups of countries, over $30 \%$ of men and women live with other people; these figures are particularly high in Spain, Latvia, and Bulgaria. Further analysis of the data (not shown on the table) reveals that, in every country, a large majority of older people who live with people other than a spouse or partner live with one or more of their adult children.

\section{Conclusions}

We started this paper by describing a threefold typology of living arrangements in Western Europe; and by asking whether living arrangements in Eastern Europe could be mapped onto this typology, or whether (with reference to Hajnal 1965, 1982) behaviour in Eastern Europe differs so systematically from behaviour in Western Europe that it is necessary to think in terms of a different type.

Within Western Europe, we may think in terms of a continuum, from a "Nordic" cluster typified by small households, early home-leaving, and an almost complete absence of the extended family; to a "North-Western" cluster occupying an intermediate position on this spectrum; and then on to a "Southern" cluster, typified by larger households, later home-leaving, and a higher prevalence of inter-generational co-residence generally.

Empirically, and in common with other research in this area (Fokkema and Liefbroer 2008), we find a good deal of heterogeneity among the Eastern European countries. One group of countries-Bulgaria, Romania, Slovakia, and Poland; and, to an extent, Slovenia-may be thought of as constituting an extreme form of the "Southern" type. These countries stand out as having some of the largest households in Europe; a virtual absence of solo living among young people; extended inter- 
generational co-residence, leading to a high percentage of extended-family households; and a relative scarcity of lone-parent families. We label this group "Eastern."

The Czech Republic and Hungary, by contrast, have aspects in common with the countries of the North-Western cluster (as noted by De Vos and Sandefur 2002 in relation to elderly people). In these countries, extended-family living is less common than elsewhere in Eastern Europe, particularly among older people; household sizes are smaller, and are rather similar to household sizes in the North-Western cluster; and the incidence of lone parenthood is again rather similar to the incidence found in the NorthWestern cluster.

The Baltic states have yet to be classified. In some respects this group of countries is rather heterogeneous, with Estonia having several features (smaller household sizes, non-marital cohabitation among parents) in common with the Czech Republic and Hungary. However, as a group, the Baltic States share a combination of high levels of extended-family living (characteristic of the "extreme Southern" household type) with some of the highest rates of lone parenthood in Europe (characteristic of countries at the other end of the spectrum).

To conclude, many of the Eastern European countries we have considered may be thought of as lying on the Nordic-North-Western-Southern spectrum which we defined earlier: the Czech Republic and Hungary lie between the North-Western and Southern clusters, while the Eastern group occupy a position more extreme than the Southern cluster, but essentially on the same spectrum. The Baltic states, however, lie somewhat off this continuum, as they combine aspects of both ends of the spectrum. Thus, to answer our original question, we assert that - to the extent it is useful to think in terms of different "ideal types" of family structure for Eastern Europe-it is only necessary to expand our typology in the case of the Baltic states.

\section{Acknowledgements}

This paper forms part of the ALICE (Analysis of Life Chances in Europe) project, funded by the UK's Economic and Social Research Council (ESRC) under grant number RES-062-23-1455. The work has also been supported by the Net-SILC programme, funded by Eurostat. Data used are from the EU-SILC UDB obtained from the European Commission (Eurostat). We acknowledge comments and suggestions from Tony Atkinson and Eric Marlier, from participants in Net-SILC meetings and the 2010 Colloquium on Cross-National Methods, and from three anonymous referees. 


\section{References}

Andersson, G. (2002). Children's experience of family disruption and family formation: Evidence from 16 FFS countries. Demographic Research 7(7): 343-364. doi:10.4054/DemRes.2002.7.7.

Bradshaw, J., Kenney, S., Kilkey, M., Hutton, S., Corden, A., Eardley, T., Holmes, H., and Neale, J. (1996). The employment of lone parents: A comparison of policy in 20 countries. In: The Family and Parenthood: Policy and Practice. London: Family Policy Studies Centre.

Brady, D. (2004). Reconsidering the divergence between elderly, child and overall poverty. Research on Aging 26(5): 487-510. doi:10.1177/0164027504266587.

Burch, T.K. (1970). Some demographic determinants of average household size: An analytic approach. Demography 7(1): 61-69. doi:10.2307/2060023.

Central Statistics Office Ireland (2007). Census 2006: Volume 3 - Household composition, family units and fertility, Table 3 - Number of private households classified by composition and size [electronic resource]. Dublin: Stationary Office. http://www.cso.ie/census/census2006results/volume_3/tables_1-9.pdf.

Chambaz, C. (2001). Lone-parent families in Europe: A variety of economic and social circumstances. Social Policy and Administration 35(6): 658-671. doi:10.1111/ 1467-9515.00259.

CIA (2009). The world factbook 2009. Washington D.C.: Central Intelligence Agency.

De Vos, S. and Sandefur, G. (2002). Elderly living arrangements in Bulgaria, the Czech Republic, Estonia, Finland and Romania. European Journal of Population 18(1): 21-38. doi:10.1023/A:1013877606584.

Esping-Andersen, G. (1990). The Three Worlds of Welfare Capitalism. Cambridge: Policy Press.

Esping-Andersen, G. (1999). Social foundations of postindustrial economies. Oxford: University Press Oxford. doi:10.1093/0198742002.001.0001.

Eurostat (2008). Year 2008. Cross-sectional data. Differences between data collected and anonymised user database [electronic resource]. European Commission. http://circa.europa.eu/Public/irc/dsis/eusilc/library?l=/data_dissemination/udb_u ser_database $/ 2008 \& v m=$ detailed\&sb=Title. 
Fokkema, T. and Liefbroer, A.C. (2008). Trends in living arrangements in Europe: Convergence or divergence? Demographic Research 19(36): 1351-1418. doi:10.4054/DemRes.2008.19.36.

Fondazione G. Brodolini (2007). Study on poverty and social exclusion among lone parents. European Commission.

Gerber, T. (2009). Changing family formation behavior in post-socialist countries: Similarities, divergences, and explanations in comparative perspective. Paper presented at the 1989: Twenty Years After Conference, Laguna Beach, California, November 5-8, 2009.

Hajnal, J. (1965). European marriage pattern in historical perspective. In: Glass, D.V. and Eversley, D.E.C. (eds.). Population in History. London: Arnold: 101-143.

Hajnal, J. (1982). Two kinds of preindustrial household formation system. Population and Development Review 8(3): 449-494. doi:10.2307/1972376.

Hammel, E.A. and Laslett, P. (1974). Comparing household structure over time and between cultures. Comparative Studies in Society and History 16(1): 73-109. doi:10.1017/S0010417500007362.

Hantrais, L., Philipov, D., and Billari, F.C. (2006). Policy implications of changing family formation. Population Studies 49. (Strasbourg: Council of Europe Publishing).

Harrington Meyer, M. (1990). Family status and poverty among older women: The gendered distribution of retirement income in the United States. Social Problems 37(4): 551-563. doi:10.1525/sp.1990.37.4.03a00090.

Hoem, J.M., Kostova, D., Jasilioniene, A., and Muresan, C. (2009). Traces of the second demographic transition in four selected countries in Central and Eastern Europe: Union formation as a demographic manifestation. European Journal of Population 25(3): 239-255. doi:10.1007/s10680-009-9177-y.

Iacovou, M. (2004). Patterns of family living. In: Berthoud, R. and Iacovou, M. (eds.). Social Europe: Living Standards and Welfare States. Cheltenham: Edward Elgar: 21-45.

Iacovou, M. and Berthoud, R. (2001). Young people's lives: A map of Europe. Colchester: University of Essex, Institute for Social and Economic Research.

Iacovou, M. and Skew, A.J. (2010). Household structure in the EU. Colchester: University of Essex. (ISER Working Paper; 2010-10). 
Kalmijn, M. (2007). Explaining cross-national differences in marriage, cohabitation and divorce in Europe, 1990 - 2000. Population Studies 61(3): 243-263. doi:10.1080/00324720701571806.

Keilman, N. (1987). Recent trends in family and household composition in Europe. European Journal of Population 3(3-4): 297-325. doi:10.1007/BF01796903.

Kilkey, M. (2000). Lone mothers between paid work and care: The policy regimes in twenty countries. Aldershot: Ashgate.

Kinsella, K. and Wan He (2009). An aging world: 2008. Washington DC: US Government Printing Office, US Census Bureau, International Population Reports. (P95/09-1).

Laslett, P. (1972). Mean household size in England since the sixteenth century. In: Laslett, P. and Wall, R. (eds.). Household and Family in past time. London: Cambridge University Press: 125-158.

Liefbroer, A.C. and Fokkema, T. (2008). Recent trends in demographic attitudes and behaviour: Is the second demographic transition moving to Southern and Eastern Europe? In: Surkyn, J., Deboosere, P., and Bavel, J.V. (eds.). Demographic challenges for the $21^{\text {st }}$ Century. A State of the Art in Demography. Brussels: VUBPRESS: 115-141.

Mandic, S. (2008). Home-leaving and its structural determinants in Western and Eastern Europe: An exploratory study. Housing Studies 23(4): 615-637. doi:10.1080/02673030802112754.

Perelli-Harris, B., Sigle-Rushton, W., Lappegard, T., Jasilioniene, A., Di Giulio, P., Keizer, R., Koeppen, K., Berghammer, C., and Kreyenfeld, M. (2009). Examining nonmarital childbearing in Europe: How does union context differ across countries? Rostock: Max Planck Institute for Demographic Research. (MPIDR Working Paper, WP-2009-021).

Reher, D.S. (1998). Family ties in Western Europe: Persistent contrasts. Population and Development Review 24(2): 203-234. doi:10.2307/2807972.

Robson, K. and Berthoud, R. (2003). Teenage motherhood in Europe: A multi-country analysis of socioeconomic outcomes. European Sociological Review 19(5): 451466. doi:10.1093/esr/19.5.451.

Saraceno, C. (2008). Patterns of family living in the enlarged EU. In: Alber, J., Fahey, T., and Saraceno, C. (eds.). Handbook of Quality of Life in the Enlarged European Union. London and New York: Routledge: 47-72. 
Smeeding, T. and Sandström, S. (2005). Poverty and income maintenance in old age: A cross-national view of low income older women. Luxembourg: LIS. (LIS Working Paper Series, No. 398).

Tomassini, C., Glaser, K., Wolf, D.A., Broese van Groenou, M.I., and Grundy, E. (2004). Living arrangements among older people: An overview of trends in Europe and the USA. Population Trends 115: 24-34.

UNICEF (2001). A league table of teenage births in rich nations. Florence: UNICEF Innocenti Research Centre (Innocenti Report Card, No. 3).

United Nations (2006). Conference of European statisticians recommendations for the 2010 censuses of population and housing. New York and Geneva: United Nations.

United Nations (2007). Principles and recommendations for population and housing censuses. Revision 2. New York: United Nations (Statistical Papers, Series M. No. 67/Rev.2). 


\section{Appendix}

Table A1: Life expectancy in years, by country

\begin{tabular}{|c|c|c|c|}
\hline & (1) Men & (2) Women & $(2)-(1)$ \\
\hline Sweden & 78.6 & 83.3 & 4.7 \\
\hline Denmark & 76.0 & 80.8 & 4.8 \\
\hline Cyprus & 75.9 & 80.9 & 5.0 \\
\hline United Kingdom & 76.5 & 81.6 & 5.1 \\
\hline Greece & 77.1 & 82.4 & 5.3 \\
\hline Netherlands & 76.8 & 82.1 & 5.3 \\
\hline Ireland & 75.6 & 81.1 & 5.5 \\
\hline Austria & 76.6 & 82.6 & 6.0 \\
\hline Italy & 77.3 & 83.3 & 6.1 \\
\hline Germany & 76.3 & 82.4 & 6.2 \\
\hline Poland & 73.1 & 79.4 & 6.3 \\
\hline Belgium & 76.1 & 82.5 & 6.5 \\
\hline France & 77.8 & 84.3 & 6.5 \\
\hline Portugal & 75.0 & 81.7 & 6.7 \\
\hline Czech Republic & 73.5 & 80.3 & 6.7 \\
\hline Luxembourg & 76.1 & 82.8 & 6.7 \\
\hline Spain & 76.71 & 83.6 & 6.8 \\
\hline Finland & 75.5 & 82.6 & 7.1 \\
\hline Romania & 69.0 & 76.2 & 7.2 \\
\hline Bulgaria & 69.5 & 76.9 & 7.4 \\
\hline Slovenia & 73.3 & 80.8 & 7.6 \\
\hline Slovakia & 71.5 & 79.5 & 8.1 \\
\hline Hungary & 69.3 & 77.9 & 8.6 \\
\hline Lithuania & 70.0 & 80.1 & 10.1 \\
\hline Latvia & 67.0 & 77.6 & 10.6 \\
\hline Estonia & 67.5 & 78.5 & 11.1 \\
\hline European Union & 75.5 & 82.0 & 6.4 \\
\hline
\end{tabular}

Source: CIA (2009) 
Iacovou \& Skew: Household composition across the new Europe: Where do the new Member States fit in? 